\title{
The Impact of Migration on Economic Growth and Human Development: The Case of the Philippines
}

\author{
Minh Doan Van \\ Dai Viet College, Vietnam
}

\begin{abstract}
This study examines the impact of migration on economic growth and human development using the selected number of migrants from 1985-2021. The panel's estimates confirm that social spending, domestic investment, including finance, income inequality, income and human poverty are significant decisive factors for human development or GDP per capita in the Philippines. The study also shows the importance of including other factors for future studies on the link between remittances and the development of the country. The policy recommendation in this research is the government needs to take appropriate measures to manage the source of migrants as well as to avoid the problem of gray matter bleeding for talents.
\end{abstract}

Keywords: Migration, Economic Growth, HDI, Philippines

*Corresponding author: Minh Doan Van; Email: minhdv.ceo1@gmail.com DOI: https://doi.org/10.37227/JIBM-2021-07-1078

\section{Introduction}

Human cross-border mobility remains a continuous global process and an important part of global integration. Migration has been seen as the movement of people between regions or countries. However, immigration and migration are often used to migrate in and out of their respective regions or countries. Migration has different effects on the growth and development of any one country. In some countries, it is considered a positive catalyst for achieving sustainable and widespread economic growth and development, while others experience or consider migration to be a step backward. The study tested the impact of migration on economic growth and human development in the Philippines, one of the countries with the largest migration population in Southeast Asia.

The movement of people between regions and countries depends on many factors that can be derived from the inside and outside. Differences in wages and government policies affecting the welfare of society, especially the active population, were identified mostly in experimental documents (Greenwood, 1969; Greenwood and Sweetland, 1972; Pack, 1973; Hare, 1999; Hunt, 2006; Gibson and McKenzie, 2011; Ackah and Medvedev, 2012; McKenzie and Salcedo, 2014) as the driving and dragging factors that led individuals and/or households to decide to emigrate. Higher wages or better work incentives from the government for skilled workers can be factors that drag down migration and/or increase immigration, while lower wages and lack of motivation for work can be factors that drive increased migration and make the home country unattractive to immigrants. 
With established push-and-drag factors driving the move outside the country, the effect of migration on the growth and economic development of countries remains an experimental question that has not been fully studied. Numerous studies (Friedberg and Hunt, 1995; De Haas, 2010; De Haas, 2012) assessed the impact of migration or remittances on economic growth, poverty, and human capital development, but most lacked experimental economic studies. However, they all point to the potentially significant effects that remittances have on economic development. However, different results were found on the relationship between migration and economic growth and development, and several recent volume economic investigations were carried out using the remittance flow as a representation of migration.

Labor migration, a prominent feature in Southeast Asia and a key engine of economic growth and development, is also tied to inconsistent human rights practices. This is especially true for low-skilled areas such as fisheries, domestic work, and construction. Meanwhile, the prospect of higher employment and wages often forces people from countries like the Philippines to move to more prosperous economies in the sub-region. Many migrants spend most of their income back to their home countries, such as the Philippines, which has always ranked among the largest remittance countries in the world. In 2010, the remittances sent by Filipinos working abroad increased by more than $\$ 21.4$ billion, ranked fourth in the world behind India ( $\$ 55$ billion), China ( $\$ 51$ billion), and Mexico ( $\$ 22.6$ billion). The number of remittances increased due to the growing demand for Filipino workers as housewives in countries with an aging population. Increased remittances have helped drive domestic consumer demand while exports have also increased sharply. However, some economists argue that the rising migration trend threatens to undermine the Philippines' long-term economic potential because the billions of dollars sent by overseas workers annually are largely not for the development of economic facilities, but to save rather than invest, so the Philippines is unlikely to grow faster.

In addition, in 2018 the Philippines, which has an international cash flow of up to $\$ 34$ billion, is the fourth-largest recipient of remittances globally after India, China, and Mexico. But even as labor migration has helped alleviate labor shortages in destination countries, many labor migrants continue to face exploitative conditions. Workers working in low-skilled, labor-free sectors, regardless of their legal status, are most affected, with wage-related abuse being the most common. Many migrant workers are forced to work long hours on wages below the minimum wage, as a result of inadequate protection provided to migrants in both recruitment and employment.

Against this backdrop, this study looked at the impact of migration on economic growth (measured in GDP per capita) and human development (measured by the Human Development Index -HDI) on the Philippines. The link between migration and growth and economic development follows growth-based, capacity-based and asset-based development approaches as Sen launched (1999), Dollar and Kraay (2002), Fukuda-Parr (2003) and Moser (2007). This approach to estimating the growth and development impact of migration is still very rare in the experience of previous this. Moreover, two measures of migration were used in the study. Firstly, the ratio of individual remittances received (the ratio of migrant income) to the individual remittance paid (the rate of immigration) was adopted and, similar to most experimental studies, was used as a measure of migration. This also combines the financial aspect - in terms of capital flows - on the impact of migration on human growth and development (Chami and associates, 2005). The second measure is the number of migrants residing in a particular country and combines the non-financial aspect of the impact of migration on human growth and development. 


\section{Literature Review}

The International Organization for Migration (IOM, 2015) defines migration is the movement of a person or a group of persons, either across an international border or within a State. It is a population movement, encompassing any kind of movement of people, whatever its length, composition, and causes; it includes migration of refugees, displaced persons, economic migrants, and people moving for other purposes, including family reunification.

Economic growth can be defined as the increase in wealth over time and it is usually measured in terms of variation in Gross Domestic Product (GDP), which comprises the entire value-added produced within national boundaries in a given timeframe. In today's economies, economic growth is usually understood as a measure of progress in which economic factors such as innovation and technology and financial and human capital play a major role beside traditional elements such as investments and entrepreneurship (Solow, 1956; Aghion and Howitt, 1998). Other features also largely contribute to determine economic growth including progresses in science and medicine, education and public health, trade and globalization, and stable and capable governments and institutions (Barro, 1998; Romer, 2008).

Migration contributes to spur innovation and economic growth. Firstly, migration has a demographic impact, not only by increasing the size of the population but also by changing the age pyramid of receiving countries. Migrants tend to be more concentrated in the younger and economically active age groups compared with natives and therefore contribute to reduce dependency ratios (Gagnon, 2014). The gains from migration are larger the younger the migrant is because younger migrants have a longer lifetime ahead of them to benefit from the extra income; hence the present discounted gains from migration are higher (IMF, 2020 WEO). Secondly, migrants arrive with skills and abilities, and so supplement the stock of human capital of the host country. More specifically, evidence from the United States suggests that skilled immigrants contribute to boosting research and innovation, as well as technological progress (Hunt, 2010). Include the level of education and skills that are in high demand in the destination countries. These factors drive the selection of people who migrate, with younger, more educated, and more skilled individuals being among those with a higher probability of emigration. Large potential monetary gains have developed an industry around migration, with recruiting firms and brokers engaging in fraudulent and abusive practices.

Better regulating the migration industry would protect migrants' workers from exploitation and substantial loss of savings and assets (World Bank, 2014). Thirdly, migrant remittances increase domestic savings as well as improve financial intermediation. According to the UNDP (2014), remittances are importance for developing countries as amount can provide access to additional financial resources and ultimately, to the creation and sustainability of livelihoods. Ratha et at (2016), examine the importance of worker's remittances as a stable source of external funding in developing countries. The economic effect of remittances increases the recipient's household income and the foreign exchange reserves of the recipient's country. In the Philippines, several studies have evaluated the effect of remittances on the economy. In 2010, one of the factors that caused the Philippines economy to grow significantly was due to the continued increase in foreign currency revenues. The growth of the Philippines is due to the number of remittances sent by Filipinos working abroad (estimated at 9-11 million people, accounting for about $10 \%$ of the total 
population). The source of bad money sent back by foreign workers in the Philippines (OFW) continues to grow and is a key pillar of the Philippine economy.

Human development means that development for humans and by humans. Human development is the knowledge, skills, capabilities, attributes, and various characteristics inherent in individuals that are related to economic activity. Also, not only focuses on the knowledge and skills that individuals possess but, on the wealth, attributes, and characteristics they possess. It is a set of skills, capabilities, and experiences that the individual acquires, and enables him to participate in economic life and gain income, which can be improved through investment in education, health care, training, and other forms of human capital (Abu Al-Ezz, 2010, p.3). Human development is also called the stock of experience, and ability to invent, and it can be acquired at all stages of life, but the ability of a person to acquire knowledge varies from one stage to another of his life years, and is affected by the health and psychological status, educational level, and environment in which he lives (interview Al-Alawneh, 2016, p.339).

Human development and economic growth are two different paradigms that imply different objectives, measurement techniques, and policies. However, several broad literatures have shown that economic growth and human development are intrinsically interconnected, co-evolutionary, and mutually reinforcing each other. Human development has recently been advanced as the ultimate objective of human activity in place of economic growth. Economic growth and human development have been empirically established to have bi-directional causality (Ranis, Stewart, and Ramirez, 2000). Investing in human capital is one of the most important factors that affect economic growth in the national economy or society. The formation of human capital does not depend only on education and training, but also on the amount of health and social services that work on building and maintaining human capital, as health and education are the main factors determining the composition of growth in production and exports. The higher the level of education achieved by the workforce, the greater the total productivity, because the more educated are the ones most likely to innovate and thus affect the overall productivity. Education also affects the growth of per capita income through vinegar. For the reduction of population growth, and the

equitable distribution of income leads to increased demand for better nutrition education and thus increase overall productivity and increase economic growth (Beine, Giading and Olaniyn, 2014, p.19).

\section{Method}

The data used in this study is taken from the World Bank Data Bank, IMF, International Financial Statistics Database and in most cases the updated data set as used in Akanbi (2015). The data covers the period from 1985 to 2021 selected. All data was accessed in 2021 and, if necessary, measured at the actual price in US dollars and expressed as a natural logarithm.

\section{Measuring Migration}

Two migration measures were passed in this study. The first measure involves a measure of the widely applied flow of money between countries, which is that financial flows are considered to offset transfers. The use of remittance flows in this study as a measure of migration is based on the idea that changes in the level of immigration or migration in a particular country will be reflected directly in the number of remittances received or paid. For example, the increased level of immigration will turn into paid remittances; likewise, the increasing level of migration will lead to higher remittances. Therefore, the rate of personal 
remittance received (in-line) compared to the individual remittances paid (outline) is used as a measure of the degree of movement.

The second migration measure relates to the number of migrants residing in a specific region of the Country. This deviation from financial flows tends to capture whether the population of migrants in a country contributes directly to growth and development. As defined in World Databank (2015), "the number of international migrants is the number of people born in a country different from the one in which they live. It also includes refugees. The data is used to estimate the amount of international migration at a specific time obtained mainly from censuses. Estimates are taken from population data (those residing in one country but born in another Country). When data on the foreign-born population is unavailable, data on the population of foreign populations (that is, those who are citizens of a country different from the one in which they reside) are used as estimates".

\section{Measuring Human Development}

The human development measures passed in this study are following the United Nations Human Development Index (UNDP) (HDI). HDI serves as a way of measuring development by combining indicators such as longevity, education level and income into synthetic HDI. HDI score is between 0 and 1 , with 0 representing the worst human development These indicators will represent the health index, education index and income index with values between 0 and 1 , lbest human development, value above 0.800 are very high, between 0.700 and 0.799 is high, between 0.550 and 0.699 is average and below 0.550 is low and 1 best human development. Most HDI points for the Philippines are high, which is a slight improvement between 1985 (0.678) and 2020 (0.718). Since the data was reported over 5 years, the rate of growth between each period is calculated, and the average growth rate per year (the rate of increase divided by the number of years ( 5 years) in the middle) has been used to create the missing data points.

\section{Measuring Poverty}

Two measures of poverty applied in this study strictly follow Akanbi's guidelines. The first measure of poverty (income poverty) follows the basic Foster-Greer-Thorbecke (FGT) index (Foster, Greer and Thorbecke, 1984). This measure has three components: the poverty rate (absolute poverty), the depth of poverty and the severity of poverty. Indicators are calculated as follows:

at

$$
P=\sum_{i=1}^{Q} \frac{1}{N}\left[\frac{Z-Y}{Z}\right]^{\alpha}
$$

$\mathrm{N}=$ population

$\mathrm{Q}=\%$ of the population living below the poverty line (proxy = poor population)

$\mathrm{Z}=$ poverty line (World Bank estimated at US\$2 per day)

$\mathrm{Y}=$ final household spending per head

$\alpha=$ parameters of disgust with poverty

$\alpha=0,(1$ and 2 respectively for the absolute level, depth and severity of poverty. In line with existing literature (Akanbi, 2011; Ghani, Iyer, and Mishra, 2012; Akanbi, 2015), the study passed the severity of poverty as a measure of poverty because it combines the level of inequality among the poor in society.) 
The second poverty gauge (non-income) after the Human Poverty Index (HPI) was developed by UNDP (1997). HPI is an aggregate index that aggregates different characteristics of deprivation (i.e., survival, knowledge, and living conditions) in the quality of life caused by non-income factors to reach aggregate conclusions about the level of poverty in a community. Therefore, the indicators are calculated as follows:

at

$$
H P I=\left[1 / 3\left(P_{1}^{\alpha}+P_{2}^{\alpha}+P_{3}^{\alpha}\right)\right]^{1 / \alpha}
$$

$\mathrm{P} 1=$ probability at birth does not survive to the age of 40

$\mathrm{P} 2=$ adult enteral literacy rate

P3 = the non-empowered average of the population does not use improved water sources and children are underweight compared to their age

$\alpha=3$ (weighted when the shortage is exacerbated)

Non-remittance average $=0.5^{*}(\%$ of the population does not use improved water $)+0.5 *$ ( $\%$ of children are underweight compared to age)

\section{Stylised Facts: Performance of Income (GDP Per Capita) and HDI concerning Migration Outcomes}

Since remittances are cash flows in foreign currencies and reach high levels in certain contexts, they offer the potential for national development. Based on existing documents and data, it is also assumed that remittances invested in human development in countries where human development is on average better in countries with low, high and very high HDI.

This is because the proportion of remittances to GDP is higher than in middle-income countries (WB, 2009) and in that context, remittances are less volatile than other foreign currency flows such as FDI, ODA, or export-related flows. Because the rate of migration from developed countries with high HDI levels is relatively low, they receive fewer remittances. Since countries with very high HDI also have well-developed markets, public interests and private insurance systems (Massey associates, 1993, p. 436), remittances are not expected to have a significant impact on a very high and high human development context.

On the other hand, in countries with low HDI, remittances also have little significant positive impact on human development due to relatively smaller remittances, in-house and market failures (Massey and associates, 1993, p (436). This theoretical proposal is also reinforced in the data set that we have created for the experimental analysis as to be explained in detail in the discussion. In the Philippines, several fundamental trends have emerged over the past two and a half decades regarding human development, GDP per capita, remittance flow and the total number of migrants.

\section{Results}

GDP per capita is expected to create a positive and two-way relationship with HDI (Akanbi, 2015). Therefore, the increase in GDP per capita needs to improve the level of human development; likewise, improving human development will lead to an increase in GDP per capita.

As mentioned earlier, income poverty and human poverty (without income) have separate origins and are used instead of each other in models. The models are enhanced by two forms of poverty as an additional variable after experimental evidence of the two-way 
cause-and-effect relationship between GDP and poverty and visual channels that have a high correlation between human poverty and human development and poverty in terms of income and GDP per capita. Therefore, the study chose to investigate the link between human poverty with GDP per capita and poverty in terms of income and human development, two variables that are expected to pose a negative relationship with HDI and GDP per capita, meaning that the level of income increase, and human poverty is directly transformed into

Figure 1: Performance of Income (GDP Per Capita) and HDI concerning Migration Outcomes child development level and GDP per capita decreased accordingly.

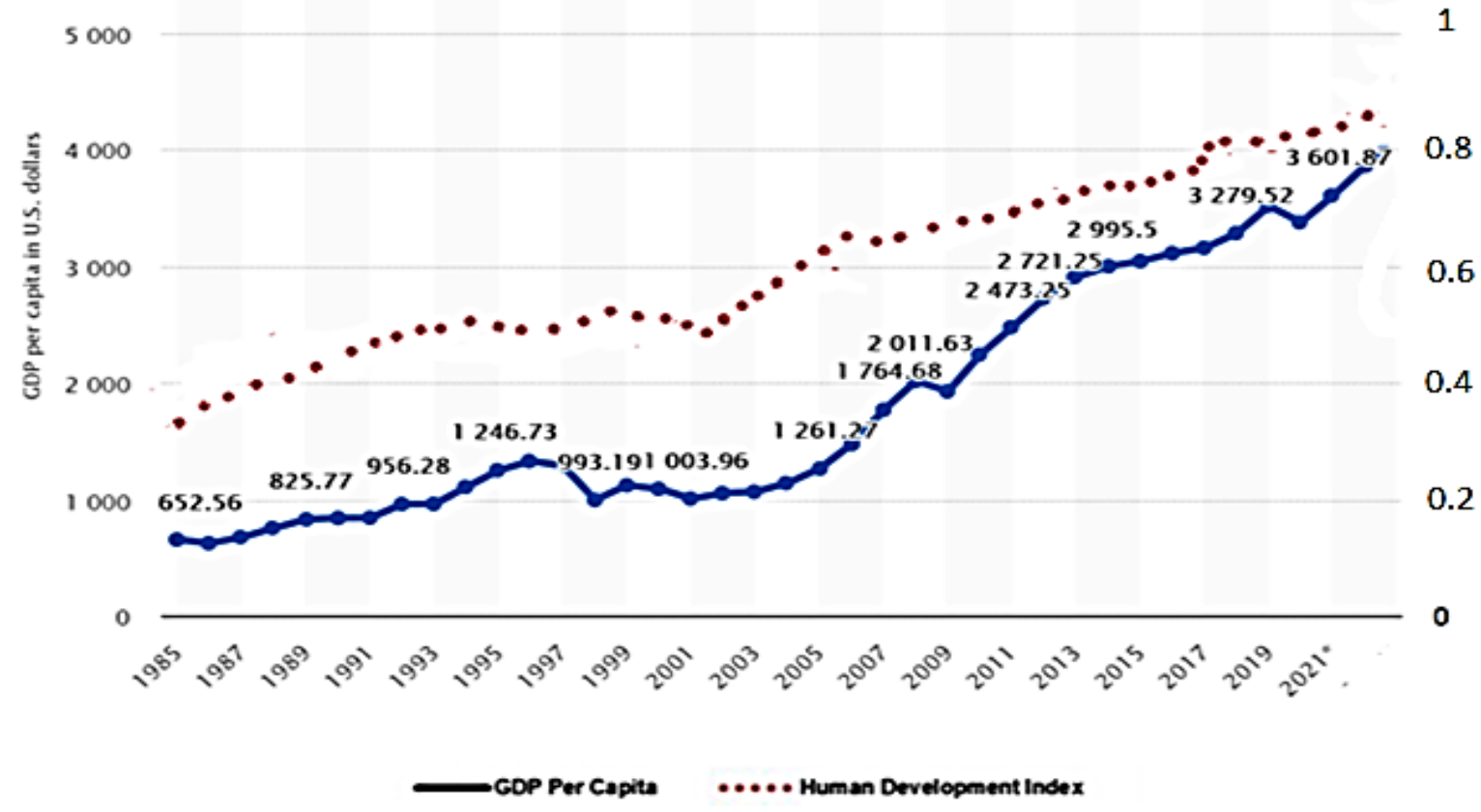

Source: World databank (2021) and authors' calculations

From Figure 1, it can be seen that GDP per capita increased on average by about 5.5\% between 1985and 2021, rising from about $\$ 652$ in 1985 to $\$ 3279$ in 2021. This increase can be sustained due to the rise of hiding - given that earnings are a component of HDI increasing the index score to 0.718 index points over the same period.

As for the personal transfers paid and received, there seems to be a difference between these two chains. Remittances tend to decline gradually, from about $1 \%$ of GDP in 1985 to about $0.33 \%$ of GDP in 2013 . Remittances received tend to increase from $1985 \%$, accounting for about $0.33 \%$ of GDP and reaching a high of about $3.2 \%$ of GDP in 2008 and then falling to about $2 \%$ of GDP in 2010. Before 1994, the number of remittances paid in the Philippines was chosen greater than the amount received from outside individual countries and then the payment fell below receipts. Despite this difference, the number of international migrants continues to increase, with an estimated 10 million Filipinos living and working in other countries (6.4 million have settled in the US). The Philippines is an important source of labor for countries in the Middle East. On average, the Philippines has about 1 million people working abroad annually. 


\section{Discussion}

This study experimentally examined the impact of migration on economic growth and human development using the selected number of migrants from 1985-2021. Estimates made after controlling other decision factors describe a firm estimate of the parameters in the model. Stylized facts presented show a favourable correlation between migration, GDP per capita and HDI, but the cause and effect from other stated estimates.

The panel's estimates confirm that social spending, domestic investment, including finance, income inequality, income and human poverty are significant decisive factors for human development or GDP per capita in the Philippines. The dual cause-and-effect relationship between human development and GDP per capita shows that the impact of human development on GDP per capita is stronger than the impact of GDP per capita on human development. In many developing countries with a strong wave of migration, governments often fall into the trap of seeing remittances as the ultimate means of development, so the state often tries to change away from its responsibilities as a supplier of public goods. This shows an important policy implication that governments need to make efforts to improve people's human capacity but not undermine efforts to develop the economy.

The development impact of remittances and measures that can be taken to facilitate the successful use of money from abroad depends on both the initial conditions in which the people go abroad, the living conditions of the recipient of remittances, the framework of the country of origin, and the socio-economic conditions of the migrants abroad. To fill in the (missing) link between remittances and local development, it is necessary to increase attention to these aspects in the analysis. This study also shows that there is a large amount of us used money and that the investment preferences of migrant households remain in the housing sector., and economic and organizational factors, i.e., lack of market opportunities, lack of infrastructure and limited attention of local development organizations. However, the use of remittances for education, improving living standards and health should be considered an important tool to increase the productivity of households. Individual investment initiatives have a certain impact (i.e., not taxi services or small cafes) not much, and immigrants complain about the inappropriateness of the tools available.

However, it is worth noting that even the best-equipped investors often avoid projects in developing countries if a small portion of remittances is invested by migrants and their households for production purposes.

The study also shows the importance of including other factors for future studies on the link between remittances and the development of the country. As in point by Ghosh (2000) Collinson (1996) Gamburd (2000) and Giubilaro (1997), the capacity of migrants, the stage of the migration project, the duration of their stay abroad and also the reasons behind their own return are factors that increasingly have to be taken into account. Therefore, changing models of migrant destinations, changes in the composition of the migrant population and growing restrictions on the movement of people are important factors that need further analysis. The influx of remittances can change drastically and create great shocks for the national economy. However, if the influx of remittances decreases due to the increase in the number of returning migrants and if these people massively invested in savings, as happened in Jordan after the First Gulf War, then a positive impact on local development can be expected (Amoroso and Gallina, 2002). Therefore, the government needs to take appropriate measures to manage the source of migrants as well as to avoid the problem of gray matter bleeding for talents. 


\section{Conclusion}

The research included analysing the impact of migration on economic development and human development index indicators for the case of Philippines. Trough the descriptive and analytical study, the research reached the most important conclusions that migration is an important phenomenon largely driven by powerful economic and labor market forces: large differentials in wages and employment opportunities, both between advanced and developing countries and within developing regions, create powerful incentives for individuals to migrate to achieve a higher income and to increase the expected income for their offspring.

Besides, one of the shortcomings of the article is that there is no quantitative measure to measure the influencing factors. Thereby, future studies on the same topic can be extensively analysed on the factors affecting each factor of human development as well as factors of economic development.

\section{References}

Ackah, C., and Medvedev, D. (2012), "Internal migration in Ghana: determinants and welfare impacts", International Journal of Social Economics, 39(10), 764-784.

Akanbi, (2017)," Impact of migration on economic growth and human development: a case of sub-Saharan African countries", International Journal of Social Economics, 44(5).

Aghion, P. and P. Howitt (1998). Endogenous Growth Theory (Cambridge, MA: MIT Press). ABU AL-EZZ. (2010) "Relationship between Human Capital and Economic Growth: Nigeria as an Example".

AL-ALAWNEH. (2016). "Human Development and Economic Growth, an Empirical Study on Jordan", Journal of Administrative and Economic Sciences, 92(22).

Amoroso, Bruno and Andrea Gallina (2002). Economies Mediterranee. Sistemi Produttivi Tradizionali e di Nuova Formazione in Dieci Paesi della Riva Sud, Rome: Cannel.

Barro, R.J. (1998). 'Determinants of Economic Growth: A Cross-Country Empirical Study'. NBER Working Papers, WP/5698 (Cambridge, MA: National Bureau of Economic Research).

Beine, G. \& Olaniyn. (2014). "Economic growth and human development - a theoretical justification"

Collinson, Sara (1996). Shore to Shore. The Politics of Migration in Euro-Maghreb Relations. London: The Royal Institute of International Affairs, Middle East Programmed.

Chami, R., Fullenkamp, C., and Jahjah, S. (2005), "Are immigrant remittance flows a source of capital for development?", IMF Staff Papers, 52(1), pp. 55-81.

De Haas, H. (2010), "Migration and development: a theoretical perspective", International Migration Review, 44(1), pp.227-264.

De Haas, H. (2012), "The migration and development pendulum: a critical view on research and policy," International Migration, 50(3), 8-25.

Dollar, D., and Kraay, A. (2002), "Growth is good for the poor", World Bank Policy $\begin{array}{lll}\text { Research Working } & \text { Paper }\end{array}$ http://elibrary.worldbank.org/doi/book/10.1596/1813- 9450-2587.

International Monetary Fund (IMF), 2020. World Economic Outlook: The Great Lockdown. Chapter 4: The Macroeconomic Effects of Global Migration. Washington DC, April.

Friedberg, R.M., and Hunt, J. (1995), "The impact of immigrants on host country wages, employment and growth," The Journal of Economic Perspectives, 9(2), 23-44.

Foster, J., Greer, J., and Thorbecke, E. (1984), "A class of decomposable poverty measures", 
Econometrica, 52(3), 761-766.

Fukuda-Parr, S. (2003), "The human development paradigm: operationalizing Sen's ideas on human capabilities", Feminist Economics, 9(2-3), 301-317

Greenwood, M.J. (1969), "The determinants of labor migration in Egypt", Journal of Regional Science, 9(8), 283-290.

Gagnon, J. (2014), "Demographic Change and the Future of the Labour Force in the EU27, in other OECD Countries and Selected Large Emerging Economies", Matching Economic Migration with Labour Market Needs, OECD Publishing, Paris.

Greenwood, M.J., and Sweetland, D. (1972), "The determinants of migration between standard metropolitan statistical areas", Demography, 9(4), 665-681.

Gamburd, Michele R (2000). The Kitchen Spoon's Handle: Transnationalism and Sri Lanka's Migrant Housemaids. Photo: Cornell University Press

Ghosh, Bimal (ed.) (2000). Return Migration: Journey of hope or despair? Geneva: International Organization for Migration and the United Nations.

Gibson, J., and Mckenzie, D. (2011), "The microeconomic determinants of emigration and return migration of the best and brightest: evidence from the Pacific", Journal of Development Economics, 95, 18-29.

Gibson, J., and Mckenzie, D. (2011), "The microeconomic determinants of emigration and return migration of the best and brightest: evidence from the Pacific", Journal of Development Economics, 95, 18-29.

Ghani, E., Iyer, L., and Mishra, S. (2012), "The poor half-billion in South Asia: is there hope for change?" Available online at: www. voxeu. org/article/poor-half-billion-southasia-there-hope-change

Giubilaro, Donatella (1997). Migration from the Maghreb and migration pressures: current situation and future prospects. International Migration Papers ILO (Geneva) No. 15.

Gagnon, J., 2014. Chapter "Demographic change and the future of the labour force in the EU27, other OECD countries and selected large emerging economies". In OECD, \& European Union (Eds.), Matching economic migration with labour market needs. Paris: OECD Publishing.

Hare, D. (1999), "'Push' versus 'pull' factors in migration outflows and returns: determinants of migration status and spell duration among China's rural population," The Journal of Development Studies, 35(3), 45-72.

Hunt, J. (2006), "Staunching emigration from East Germany: age and the determinants of migration", Journal of the European Economic Association, 4(5), 1014-1037.

Hunt, J. (2010), “Skilled Immigrants' Contribution to Innovation and Entrepreneurship in the US", Open for Business: Migrant Entrepreneurship in OECD Countries, OECD Publishing, Paris,

Massey, Douglas S., Joaquin Arango, Graeme Hugo, Ali Kouaouci, Adela Pellegrino, and J. Edward Taylor (1993). Theories of International Migration: A Review and Appraisal, Population and Development Review. 19(3) pp. 431-466.

Moser, C.O.N. (2007), Reducing global poverty: The case for asset accumulation. Washington, D.C.: Brookings Institution Press.

Pack, J.R. (1973), "Determinants of migration to central cities," Journal of Regional Science, 13(2), 249-260.

Sen, A. (1999), Development as freedom. Oxford: Oxford University Press.

Solow, R.M. (1956). "A contribution to the theory of economic growth". Quarterly Journal of Economics, 70, 65-94.

UNDP (2014). Sustaining Human Progress: Reducing Vulnerabilities and Building 
Resilience. (New York: United Nations).

Ratha, D., Eigen-Zucchi, C., and Plaza, S., (2016). Migration and remittances Factbook 2016. World Bank Publications.

Ranis, G., F. Stewart, and A. Ramirez (2000). 'Economic Growth and Human Development'. World Development, 28(2), 197-219

Romer, P. (2008). Economic Growth, The concise encyclopedia of Economics, second edition, (Stanford: Library of Economics and Liberty)

World Databank, (2021), World Development Indicator. Available online at: http://databank.worldbank.org/data/reports.aspx?source=world-developmentindicators 